\title{
Corpo e imagem em movimento: há uma alma neste corpo*
}

\author{
Regina Pollo Müller \\ Professora do Departamento de Artes Corporais - UNICAMP
}

\begin{abstract}
RESUMO: Um ritual xamanístico de iniciação realizado pelos Asuriní do Xingu para ser gravado em vídeo é analisado bem como o próprio vídeo, abordandose o tema da transmissão de conhecimento nesta sociedade a partir da experiência social contextualizada historicamente e realizada no âmbito do que se pode chamar de performances culturais. Nessa experiência, conceitos como representação, imagem, substância vital foram ressignificados, na performance corporal que expressa estes conteúdos, os mesmos que constituem as mensagens transmitidas e igualmente ressignificadas através do meio tecnológico de expressão do pesquisador. Essa experiência intercultural proporcionou reflexão antropológica sobre processos que envolvem transformação e continuidade cultural em sociedades indígenas, particularmente, a produção de sentido e de noções de conhecimento que dão expressão à experiência vivida como reflexividade transformadora.
\end{abstract}

PALAVRAS-CHAVE: Perfomance cultural, ritual xamanístico, imagem, representação, Antropologia da Experiência, Asuriní do Xingu.

\section{Introdução}

Neste estudo, o tema da transmissão de conhecimento em sociedades indígenas é tratado a partir da experiência social de seus membros, contextualizada historicamente e realizada no âmbito do que se pode chamar de performances culturais (Singer apud Turner, 1988: 21). 
Pretende-se abordar, dessa maneira, aspectos cognitivos da socialização de uma perspectiva processual, própria dessas manifestações e nas quais diversos meios de comunicação de conteúdos da cultura se combinam, tais como a música, a dança, as artes visuais, a representação cênica, além dos aspectos propriamente linguísticos, como a narrativa mítica ou qualquer outra forma de expressão verbal.

Com relação ao conceito de performance cultural que Turner toma de Singer, duas observações são necessárias nesta introdução de modo a explicitar a análise e seus pressupostos. Destaque-se, primeiramente, que sua relação com um sistema social ou configuração cultural não é a de meramente refleti-los ou expressá-los, unidirecionalmente, mas sim de reciprocidade e reflexividade, "freqüentemente uma crítica, direta ou velada, da vida social da qual se origina, uma avaliação do modo pelo qual a sociedade lida com a história" (: 22). Em segundo, considera-se nessas manifestações o caráter plural da reflexividade, quanto à grande variabilidade da ação, alocando a alguns o papel de agentes de transformação e a outros, o de pessoas sob processo de transformação, podendo ainda essas posições serem trocadas, a mesma pessoa sendo sujeito e objeto. Variabilidade de ações e variabilidade de meios de comunicação fazem que desses gêneros performativos emerjam significados que resultam da união do script com os atores e audiência, num dado momento e no processo social em curso (Turner, 1988: 24). A mesma mensagem em diferentes meios é na verdade um conjunto de mensagens sutilmente variáveis, resultando numa "parede de espelhos - espelhos mágicos, cada qual interpretando bem como refletindo as imagens lançadas nela, e emitidas de um para outro" (idem).

Usa-se aqui o conceito mais amplo de performance cultural para o objeto deste estudo, ou seja, o ritual, a fim de se salientar um aspecto, em particular, dessa experiência social, a experiência estética, e a forma estética em questão: performance e processo na ação ritual. Isto porque, na perspectiva teórica e de acordo com o tema da pesquisa realizada, buscase considerar esta forma como a estrutura (frame) a partir da qual conteúdos 
dados da cultura(noções e valores), a tradição ou o passado são reelaborados, num presente, com vistas a um futuro, a se garantir a continuidade e reprodução em processo, o modo pelo qual a sociedade se coloca perante a história. Subjacente a este entendimento está a concepção de Turner sobre a relação entre o ritual e a fase reparadora do drama social e entre a fase liminar do processo ritual e as artes da performance, entre o liminar e o liminóide, respectivamente (Turner, 1990).

De outro modo, é o caráter experiencial e processual do ritual bem como sua compreensão como "unidade de observação" e "experiência concreta" que permitem relacionar, neste trabalho, processo sociocultural, história e socialização (transmissão de conhecimento e aprendizagem) através do estudo da arte e do ritual na sociedade indígena. As performances culturais são "experiências concretas" e "unidades de observação", ou seja, "constituintes elementares" da cultura pois possuem "uma medida de tempo limitada, ou pelo menos um começo e um fim, um programa organizado de atividades, um conjunto de atores, uma audiência e um lugar e ocasião de performance". Além disso, "são coisas que alguém não pertencente à cultura em questão pode observar e compreender numa única experiência direta" (Singer apud Turner, 1988: 23).

Na construção de uma antropologia da performance que julga ser parte da antropologia da experiência, Turner recorre a outra categoria analítica, a meu ver complementar a de performance cultural, como unidade de observação. Trata-se de uma categoria resgatada do pensamento sociológico de Dilthey, as estruturas de experiência, unidades estruturadas de experiência ou unidades de experiência cujo aspecto formal induz à explicitação do vivido, ou seja, para ser completa toda experiência é expressa, comunicada em termos inteligíveis aos outros, lingüisticamente ou de outro modo qualquer. Para Dilthey, segundo Turner, as estruturas da experiência se distinguem das "estruturas cognitivas secas, estáticas e sincrônicas, centrais ao pensamento estruturalista francês, apesar de a cognição ser um aspecto, dimensão ou faceta importante de qualquer estrutura de experiência”. O pensamento clarifica e generaliza a experiência 
vivida, mas a experiência é carregada de emoção e vontade, fontes de julgamento de valores e preceitos, respectivamente. Além do momento da comunicação da experiência aos outros como constitutivo da unidade de experiência, interessa destacar para o argumento aqui desenvolvido sobre o caráter reflexivo, transformador e processual da experiência estética no ritual, a evocação de experiências passadas que são revividas através dos sentimentos a elas relacionados pois o significado é gerado pelo pensamento "sentimental" da interconexão entre eventos passados e presentes (Turner, 1982: 13 e14).

Estruturas de experiência são respostas cognitivas, afetivas e volitivas dos seres humanos aos desafios naturais e socioculturais, as quais interligam eventos críticos tais como os dramas sociais, dando a eles continuidade tensional e sentido. Há uma relação estrutural entre componentes afetivos, cognitivos e instintivos no que Dilthey chama experiência vivida, relação esta bastante evidente na estrutura sequiencial característica do drama social (1988: 48 e 90).

É na performance de uma expressão da experiência vivida que se pode, segundo Bruner, reexperienciar, reviver, recriar, recontar, reconstruir e remodelar uma cultura. A performance não libera um significado préexistente que esteja dormente no texto, mas ela própria é constitutiva do significado pois este está sempre no presente e não em manifestações passadas como, por exemplo, em origens históricas ou nas intenções de um autor. Dar voz e expressão a um texto, torna-o texto realizado (performed text), ativo e vivo, "coloca a experiência em circulação" (Turner apud Bruner, 1986: $11 \mathrm{e} 12$ ).

A transmissão cultural, que se considera aqui parte do processo de socialização, ocorre simultaneamente nas experiências e expressões da vida social, pois é processo de interpretação, retellings. É através da expressão da experiência que as culturas articulam seus significados, articulam passado e presente e por isso podem ser melhor comparadas através de seus rituais, suas artes cênicas, contos, óperas do que através de seus hábitos. Da maneira como Dilthey e Turner entendem experiência ou unidades de 
experiência, estas emergem do cotidiano sendo necessariamente expressas como sequiências isoláveis marcadas por começo, meio e fim nas quais os membros de uma sociedade manifestam o que é mais significativo sobre suas vidas. "The flow of experience is constantly arrested by reflexivity" (Turner \& Bruner, 1986). Em Geertz, encontramos a mesma compreensão de que as expressões culturais e performances não são meramente reproduções (reflections) da sociedade mas metacomentários sobre a sociedade (:21).

É justamente a reflexividade inerente à natureza experiencial, processual e expressiva do ritual que desejo pontuar nesta introdução como a principal questão a ser investigada quando se estuda transmissão cultural e processo de socialização. $\mathrm{O}$ aspecto estético da experiência, seu componente expressivo ou seu caráter de metacomentário, constitui igualmente recorte analítico fundamental ao enfoque deste estudo que se baseia na premissa da teoria de Turner de que a experiência estrutura as expressões mas estas estruturam a experiência, menos "como um círculo estático e mais como uma espiral evolucionária histórica, uma progressiva construção e reconstrução" (: 16). As expressões estéticas, estruturas de significação em performance, fluxo e reflexividade da vida social no presente, articulam passado e futuro e evidenciam, conforme o argumento principal deste trabalho, aspectos importantes a serem considerados no estudo do tema da transmissão de conhecimento.

Este estudo trata dos Asuriní do Xingu, contatados em 1971, cuja pesquisa iniciada em 1976 vem abordando a arte, o ritual e a cosmologia com resultados etnográficos que permitem aprofundar questões colocadas pela antropologia da experiência e pela antropologia interpretativa que lidam fundamentalmente com a relação entre cultura e história, discurso e estruturas de significação.

A performance de rituais realizados nos últimos cinco anos é analisada a partir de aspectos formais como o movimento do corpo no espaço e, através de depoimentos e exegeses que acompanharam essas realizações, construiu-se uma interpretação a respeito de como experienciam mudança 
cultural, transmissão cultural, reelaboração de significados, retellings sobre sua vida social no processo histórico intercultural em que se encontram pelo menos há 25 anos.

Nesta etnografia há de se destacar a própria experiência do pesquisador que ao se utilizar de meios tecnológicos de registro e divulgação dos resultados da investigação, o vídeo, introduz nova forma de reflexividade expressiva na realidade social dos sujeitos dessa história. Reflexividade e metacomentário sobre a própria expressão/representação da experiência xamanística, interpenetrando-se noções como princípio vital e imagem, "alma" e "desenho", e a televisão como "caixa de alma", na qual "entra o desenho" das pessoas e fica guardada sua "sombra".

O que está na televisão, a imagem em movimento, é princípio vital e sombra, como traduzem a noção de ynga, algo que se move. Mas ao mesmo tempo é "desenho", ayngava, guardado na televisão, mas também em movimento. O vídeo realiza concretamente, esteticamente; noção abstrata que relaciona princípio vital e imagem, realidade e representação, corpo e alma, não hierarquicamente, mas conforme princípio estruturante desta sociedade, a relação isso e aquilo (Müller, 1990: 15). Este princípio pode ser historicamente tematizado e cosmologicamente apresentado em variações que façam jus à multiplicidade e riqueza do intrincado mundo dos espíritos, cujas posições intercambiáveis garantem o framework de suas mais recentes e inusitadas experiências com o outro, os brancos e outros índios.

Um ritual xamanístico de iniciação realizado para ser gravado em vídeo pela pesquisadora será analisado bem como o próprio vídeo, fruto desta experiência, resultados que problematizam as relações corpo e alma, imagem e movimento, a partir da análise da performance, da unidade de experiência em questão, o ritual feito para a televisão, fluxo da vida social, estrutura de significação em processo. 
Revista de Antropologia, São Paulo, USP, 2000, v. 43 n².

\section{O ritual xamanístico como unidade estruturada de experiência: corpo em movimento e experiência de significado}

Emestudo ${ }^{1}$ sobre o xamanismo Asuriní e em particular sobre a ação ritual enfocando o movimento do corpo, concluí que as sensações de "suspensão/ boiar" e a de "deixar cair/afundar" associadas às qualidades do movimento (Laban) propiciam experiências psicossomáticas passíveis de observação nas ações corporais e que são, ainda, experiências do significado da noção de coexistência dos seres em diferentes planos cósmicos, presença dos espíritos entre os humanos e viagens dos xamãs a outros mundos do cosmo. A alternância das ações que resultam da combinação de fatores da qualidade de movimento, socar e deslizar, é entendida como marca formal desse discurso não-verbal, cuja organização em torno de objetos semânticos, as sensações de "suspensão" e "deixar cair", se dá como tensão. Dançase "deslizando", no convite aos espíritos para virem participar, tomar junto o mingau, fumar o charuto de tabaco. Dança-se com movimento forte, rápido, "socando", na forma agressiva de se tirar a causa da doença do

corpo dos pacientes. Na tensão entre o convite e a agressão, enfrenta-se os espíritos ameaçadores, pois podem causar a morte, mas se convive com eles, cuja intervenção garante a cura, transmitindo o ynga (princípio vital) aos pacientes, através do xamã que deles o recebe, no yvara (objeto ritual), para onde são convidados a se hospedar. Em 1993, na pesquisa de campo que deu origem a este estudo, observou-se que nos rituais xamanísticos realizados a tensão entre esses movimentos mostrava-se muito mais enfatizada na medida em que após duas execuções do ritual invocou-se espíritos mais ferozes, os quais são chamados em situações de perigo, risco de morte para ser realizada a "festa grande", como Matuia e Takiri chamaram a intensificação do movimento da dança na ação ritual presenciada.

Os Asuriní viviam em 1993 nova situação de relacionamento com os brancos e outros índios em comparação à situação em que se encontravam 
até 1985, quando sua aldeia se localizava às margens do igarapé Ipiaçava. Nesses vinte anos, desde a época do contato, sofreram mudanças profundas decorrentes das relações que se estabeleceram com a sociedade nacional e com outros povos indígenas. Estas mudanças dizem respeito à organização social relacionadas a uma drástica redução demográfica ocorrida entre a data do contato (1971) e meados da década de 1980, quando se inicia um processo de recuperação com certas peculiaridades ${ }^{2}$. $\mathrm{O}$ aumento da população infantil com alteração na composição do grupo familiar (aumento do número de filhos na família nuclear), decréscimo nas faixas de idade de jovens e adultos conformando uma pirâmide demográfica falha e invertida, desaparecimento de vários xamãs e líderes de grupos domésticos e casamentos interétnicos (com índios Parakanã, Arara e Kararaô) resultaram em novos padrões de relacionamentos, novos comportamentos sociais e rearranjos na participação em rituais e na liderança das demais atividades internas e externas ao grupo.

A convivência com missionários religiosos e a intensificação do convívio com os brancos da cidade de Altamira influenciou mudança de comportamentos, subordinada à falta de alternativas econômicas que os pudessem livrar da dependência destes e de funcionários da Funai, órgão de assistência do governo junto ao qual buscam suprir necessidades criadas com o contato.

Com relação aos rituais, jovens do sexo feminino que, na década de 1970, se dedicavam à dança dos rituais xamanísticos passam a cuidar de uma prole, às vezes numerosa. Havia, em 1993, um único rapaz na faixa de idade na qual se recruta uma das principais funções rituais, o wanapy, espécie de auxiliar e mensageiro que articula o consenso entre os grupos domésticos para a realização do ritual xamanístico. Este rapaz resistia então a desempenhá-la, numa atitude crítica estimulada pelo missionário evangélico e por suas freqüentes visitas à Altamira.

Com a mudança da aldeia para as margens do rio Xingu, os contatos dos Asuriní com os habitantes brancos aí localizados tornaram-se mais frequientes, discutindo-se agora questões como o direito de pescarem em 
águas do território Asuriní e servirem de prepostos de exploradores de madeira da região que o têm invadido. As relações com os ribeirinhos, que antes eram amistosas (junto a eles obtinham, por exemplo, cães cuja criação é bastante valorizada) e pouco freqüentes, passaram a ser de conflito, assim como também podem ser dessa maneira classificadas as relações com índios de outros grupos, com resultados desastrosos como assassinatos e processos de expulsão traumáticos. É o caso de um índio Arara com duas esposas e quatro filhos, cuja expulsão deixa um grupo de mulheres em situação de penúria, pois só com mulheres (fazia parte ainda do grupo a mãe de uma delas) e crianças, a alimentação proveniente da caça, da pesca e da agricultura reduzir-se-ia sensivelmente.

Da mesma maneira como há vinte anos chamava a atenção entre os Asuriní um processo de extinção física que se fazia acompanhar de extrema vitalidade cultural manifesta em extensos rituais, na década de 1990, observa-se igualmente a realização de rituais xamanísticos executados com os mesmos detalhes formais, exatamente os mesmos da parafernália ritualística e do desempenho da dança e do canto de outros tempos, mesmo se rearranjando o quadro de atores, com participação de mulheres e homens mais velhos nas funções de wanapy e uiratsimbé (jovem auxiliar e dançarina principal).

Em 1997, no ritual que mais adiante será descrito, participou como dançarina principal uma jovem de 14 anos, a primeira nesta idade a não ter filhos nesta faixa etária que foi gerada a partir de meados dos anos 80. A participação de jovens e crianças continua sendo incentivada, à revelia dos novos comportamentos impostos pela convivência com missionários, outros índios, visitas freqüentes à cidade; da mesma maneira como o maraká, o ritual xamanístico, continua bastante presente na vida social dos Asuriní.

Por outro lado, nesta década, os Asuriní passam a organizar, com o incentivo do chefe do Posto Indígena, expedições para expulsar invasores, embargar o produto da pesca de brancos em seu território, a participar de reuniões promovidas pelo Conselho Missionário Indigenista, órgão do 
Conselho Nacional de Bispos do Brasil, do movimento católico de defesa dos direitos das populações indígenas. Reivindicações à sociedade nacional, enfrentamento de inimigos locais e atritos com índios de outras etnias passam a fazer parte da experiência social Asuriní, expressa nos rituais que reelaboram conteúdos da cosmologia na qual está previsto o convívio amistoso e agressivo com seres diferentes.

Na conclusão de um dos trabalhos que resultaram desse estudo, afirmo que os Asuriní "vêm mantendo nestas mudanças padrões estruturais, valores éticos e morais, sua visão de mundo, internalizados fundamentalmente através dos rituais. Incorporou-se principalmente, do nosso ponto de vista, nesta dinâmica cultural, através das representações da performance ritual, a experiência histórica de contato com os brancos e outros índios. A convivência irreversível com seres diferentes, amistosa e ameaçadora, é vivida na ação ritual, estando prevista na cosmologia. A ação ritual possibilita sua reelaboração. A noção de concomitância de planos cósmicos e a convivência com seres diferentes são vivenciadas pela metamorfose do pajé nos rituais xamanísticos" (Müller, 1994a). E, em outro estudo, concluo que "a performance permite que os 'outros' também participem, como público" pois "na ação ritual do maraká, a própria relação entre o 'falante' (o performador) e o 'ouvinte' (os demais membros do grupo, entre eles os que assistem e também aqueles que participam da performance) faz parte da significação" (Müller, 1990: 201). Os Asuriní tinham no ritual que invocou os espíritos ferozes em 1993 uma assistência formada por brancos e outros índios que vivem na aldeia: os funcionários da FUNAI, missionários católicos e evangélicos, a antropóloga, índios Arara e Kararaô. O significado do enfrentamento e convivência, do contato amistoso e agressivo, emergia na performance, "da união do script com os atores e audiência num dado momento e no processo social em curso".

Nesta análise, tratou-se de demonstrar a reelaboração de conteúdos da cosmologia de modo ao grupo dar sentido à nova situação, dar expressão à experiência vivida, a convivência irreversível com outros seres que ameaça mas da qual hoje dependem. 
No caso que será analisado a seguir, a própria expressão é reelaborada. No ritual realizado para a televisão, na narrativa do sonho do xamã sobre suas viagens aos mundos dos espíritos, parte do processo de iniciação é captada pela câmera de vídeo, os ninhos dos pássaros-onça pelos quais passa o xamã na narrativa tradicional são substituídos por helicópteros e caminhões. Em lugar do ato de assoprar e sugar o corpo do paciente para obter a cura terapêutica do sistema xamânico Asuriní, Takamuim conta como aprendeu a fazer cirurgia, cortando a barriga de um peixe, no melhor estilo da medicina ocidental. Devido ao fascínio que sobre ele exerceu o fato de seu filho, vítima de acidente que perfurou o abdome, ter sido curado através de uma cirurgia em hospital de Belém do Pará, Takamuim, que sempre admirou a medicina do branco, incorporou uma de suas técnicas na sua formação como xamã, realizada entretanto, tradicionalmente, através da viagem cósmica e orientada pelos espíritos xamãs primordiais (Müller, 1990: 190).

Ante a câmera e a televisão, os Asuriní também reelaboram os conceitos ynga e ayngava, princípio vital e imagem, "alma"/sombra e desenho, bem como suas concepções sobre captação de imagem e morte / "perda da alma".

\section{Imagem e movimento: reelaboração da expressão}

Oreayngava onhynhyn oreynga pupé: "nosso desenho está entrando (dentro da televisão), nossa sombra fica dentro" ou entre o corpo e a imagem em movimento na TV há um alma, desenho e sombra.

Em 1993, passei a utilizar documentação em vídeo dos rituais Asuriní, primeiramente como registro de dados para a análise, uma vez que a dança e o corpo em movimento se tornaram objeto de estudo da pesquisa. Em 1995-1996, com a possibilidade de obter melhor qualidade de imagem, através da participação de equipe técnica no trabalho, o vídeo serviu como meio de divulgação de resultados da pesquisa. Finalmente, com o vídeo Morayngava, em 1997, o levantamento de dados, a análise e a divulgação 
dos resultados da pesquisa foram realizados no processo de roteirização, captação de imagens e edição.

O objetivo inicial da realização deste vídeo foi o retorno aos Asuriní dos vídeos anteriormente realizados, como parte do projeto $O$ Turé dos Asuriní do Xingu, que propunha o registro videográfico como instrumento metodológico fundamental para análise e divulgação de resultados do estudo sobre ritual no contexto interétnico, sob a perspectiva de sua intersecção com outros discursos e enfocando privilegiadamente seu aspecto não-verbal. Além de se considerar o vídeo como instrumento de pesquisa, considerou-se como objetivo deste projeto divulgar a cultura Asuriní e a inscrição histórica deste povo indígena, através da abordagem de suas próprias respostas às ameaças a sua sobrevivência, tal como interpretei a realização de rituais pelos Asuriní (Müller, 1994a e1994b). Justificava-se ainda, no projeto, que esta divulgação, por sua vez, pode ser incorporada a esta mesma inscrição na medida em que se amplia o universo dos interlocutores/público para além dos membros da sociedade Asuriní e dos brancos e outros índios que convivem no seu dia a dia. Em 1995, foi registrado o ritual das flautas, retomado em sua integridade no ano anterior, após 12 anos sem ser realizado. Na continuidade desse projeto, a exibição dos vídeos com suas imagens teve como objetivo verificar com os Asuriní especialmente sua compreensão sobre esta segunda premissa, ou seja, a importância do registro e divulgação.

$\mathrm{Na}$ elaboração do roteiro, outros objetivos foram estabelecidos incorporando-se esta etapa do projeto de vídeo às pesquisas então em andamento ${ }^{3}$, a saber, realizar reflexão sobre o uso da imagem em movimento na pesquisa antropológica, investigar as noções de representação e imagem na arte Asuriní e abordar a transmissão de conhecimento através das práticas rituais, no contexto intercultural. Assim, o roteiro do vídeo constituiu o plano das atividades desenvolvidas na aldeia:

1- sessões de projeção de vídeos;

2- entrevistas com mulheres sobre desempenho de funções rituais e política demográfica atual do grupo; 
3 - entrevistas com homens e mulheres sobre transmissão de conhecimento na aprendizagem de práticas rituais e artísticas;

4 - entrevistas com homens e mulheres sobre compreensão e conceituação da televisão e do vídeo e o interesse no mesmo como veículo de informação e registro da cultura.

Além dos vídeos sobre os Asuriní, foram exibidos vídeos de outros grupos indígenas e filmes de ficção. As entrevistas foram realizadas a partir dessas exibições sobre os temas acima e outros depoimentos colhidos nessas entrevistas compreenderam narrativas de sonhos e de mito suscitadas pelo ritual xamanístico executado durante a pesquisa de campo. A exibição de vídeos de outros grupos indígenas ${ }^{4}$ que tratam de temas como identidade, defesa de direitos, política indigenista e manifestações expressivas (rituais em particular) e, certamente, a exibição de suas próprias imagens despertaram o interesse dos Asuriní em aproveitar as condições que se apresentavam com nosso trabalho, para se registrar um ritual xamanístico. No terceiro dia de nossa estadia na aldeia, numa demonstração de que mais rápidos do que a própria pesquisadora em busca da resposta dos Asuriní sobre a documentação de seus rituais e em meio às reflexões suscitadas nas entrevistas sobre a transmissão da cultura entre gerações, Manduka e Takamuim notificaram-me que não só compreenderam esse aspecto pragmático do registro em vídeo como, mais pragmáticos ainda, acrescentaram ao roteiro inicial de captação das imagens a iniciação de um xamã para que ficasse registrado, "para não perder", "como se faz pajé". A "festa do veado", Arapoás, ritual xamanístico que invoca espírito do mesmo nome, seria realizada para que o próprio Takamuim se tornasse um xamã. Manduka me pediu para interceder junto a Murey'ra solicitando sua participação como xamã principal, condição necessária para a realização do Arapoá e na qual seria auxiliado por Voaiva e Baiô ${ }^{6}$. Deixei que eles próprios resolvessem a questão da produção do ritual, preocupada inutilmente com uma interferência que já havia sido instaurada.

Não só Murey'ra participou, na função de xamã principal, como Atyva, filho de Baiô, foi wanapy, e Parakakynha, uirasimbé, auxiliar e dançarina 
principal, respectivamente. Atyva e Parakakynha são jovens (16 e 14 anos), primeiros representantes da geração que é fruto da política demográfica que o grupo implementa nos anos 80 no sentido de alterar padrões tradicionais de procriação ${ }^{7}$ com vistas a aumentar a taxa de natalidade e fazer frente à ameaça de extinção. Outras jovens, crianças na década de 1970 (Tovavyrym, Tapakaí, Taimbyra), foram mães e tiveram de ser substituídas nos rituais xamanísticos por mulheres mais velhas sem filhos (Burí, Taraveiuvi, Tupaverí), nos últimos 15 anos. Depois de Murumanak, única criança do sexo masculino em 1976, apenas Atyva tem idade agora para ser um wanapy jovem, função também desempenhada nesses 15 anos por homens mais velhos num esforço do grupo suprir falhas na sua demografia para garantir a realização de seus rituais. Nos depoimentos de mulheres no vídeo Morayngava faz-se referência a esta relação entre a política demográfica adotada pelo grupo e à dificuldade de participação das mulheres nos rituais.

O depoimento de Mará enfatiza ainda o fato de que não poder participar dos mesmos impede o aprendizado, acrescentando também seu interesse na televisão que pode "pegar sua cultura” para ser transmitida. Este depoimento remete a duas questões desta pesquisa: a forma de transmissão do conhecimento pela prática, pelo fazer, e a avaliação positiva dos Asuriní sobre a utilização de um instrumento tecnológico da sociedade do branco a serviço da transmissão e reprodução da cultura.

A respeito do primeiro assunto, outros depoimentos reforçam suas considerações como o de Okina, por exemplo, que afirma ter aprendido "sozinha" ouvindo sua avó, dançando, dançando, até que um dia foi obrigada a assumir a função de conduzir o ritual, até hoje exercida por ela (tauvyva, no ritual Tauva, nome do ser sobrenatural invocado, cuja existência no passado mítico é o da mulher detentora do saber da agricultura). Okina afirma ainda a necessidade de que as mulheres mais jovens aprendam com ela, enquanto estiver viva, a mesma exortação sendo feita por Murey'ra para que os homens aprendam a fazer o trançado no arco de uso ritual (yvyrakwasiat). Manduka também chama a atenção para a necessidade 
de se passar o conhecimento entre as gerações, mencionando o fato de não haver se interessado em aprender com o pai quando este era vivo. Lamenta não ter registro dos cantos realizados por seu pai pois, apesar de terem sido gravados, as fitas se perderam. Faz uma autocrítica, dizendo que, como não aprendeu, agora Kurijá, um dos Asuriní mais velhos, líder de grupo doméstico e respeitado pelos conhecimentos dos saberes rituais, ri de sua incompetência. Ele e Apebu, em depoimento sobre o registro em vídeo de seus rituais, enfatizam a importância das novas gerações reproduzirem-nos e para isso a necessidade de aprenderem com os mais velhos. Manduka diz "a televisão pegando o turé (ritual cosmogônico das flautas do mesmo nome, documentado no vídeo exibido a eles), pegando o que está pegando agora, as crianças quando crescer vão ver, as crianças vão ver os que morreram fazendo festa. Vão ver como é que faz festa. Como meu pai morreu eu também vou morrer, ninguém fica vivo para sempre(...)". E Apebu repete em seu depoimento: "Pode pegar nosso canto/dança(oforahai), para quando nós morrermos as crianças poderem ver como fazíamos festa".

Já Matuia se preocupa em reproduzir a tradição através da própria participação das crianças e jovens nos rituais, exortando sua filha a dançar, a partir de seu próprio exemplo: "Quando ia à festa era para dançar, só dançava, a noite todinha", "quando as velhas estão dançando estão ensinando as novas", "minha mãe dançava atrás de mim para eu aprender, me levava para dançar, me acompanhava", "antes eu era dançarina da festa de tauva $a^{8}$, dançarina da festa de tivá, da festa de kavara, punha pluma de gavião na cabeça, na festa de kavara não ficava só olhando não, agora só ficam olhando". Outra parte de suas recomendações à filha faz referência aos novos padrões de comportamento na geração de filhos que se chocam com as práticas tradicionais de participação de mulheres jovens nos rituais xamanísticos: "Quando eu era moça passava urucu para cantar (dançar), cabelo cortado. Agora é diferente, não querem. Agora tenho filho, não posso usar, agora é você que deve usar como eu usava. Agora é sua vez. Agora você vai ficar moça e logo vai querer ter filhos. Eu, Myrá, 
Apeona ficamos sem filho até mais velha, não tivemos filho novinha. Parakakynha já está moça mas ainda não tem filho, usa missanga. Meu filho está aprendendo com os outros a não cortar cabelo redondo. Quando você for dançar você deve usar o colar. Antes, quando era moça, não queria filho, só queria pintar, jenipapo, urucu. Agora não querem dançar, só querem ter filho. Agora só vão olhar a festa, nem dançam. Quando não tem filho, pode dançar. Agora não tem ninguém para ajudar a dançarina da festa do pajé, não tem ninguém para dançar com ela. Vocês querem filho logo, querem filho antes da idade que antigamente as mulheres tinham antes de ser velha pouquinho".

Em seu depoimento, Mirabô fala o seguinte sobre este assunto: “Antes as mulheres dançavam, agora não dançam mais. Filho não deixa dançar. Branco pergunta para mulher Asuriní 'por que não tem filho?'. Filho não deixa dançar. Filho, filho, filho, aí não pode dançar. Agora que as meninas estão crescendo, estão dançando".

Mará também se manifestou a respeito de sua maternidade, participação nos rituais e aprendizagem: "Meu pai era dono de festa (maritykaiva). Se eu fosse homem seria como meu pai, maritykaiva. Tenho muitos filhos, eles não me deixam fazer. Falam para eu não fazer, aí eu deixo, não faço. Eu queria ser dona da festa do espírito da água (tauvyva). Mas falaram que eu era feia, não sabia fazer, então fui ter filho. Tenho muitos filhos, eu tenho filho e danço. As outras que têm filho, quando me vêem dançar, também dançam. Dizem que quem tem filho não pode dançar, mas eu danço, as outras dançam. Falam mal de meus filhos e eu não gosto. As mulheres ficam falando que vão fazer a dança do Tauva. Mas não fazem. É fácil fazer. É bom mulher que sabe dançar comigo para eu aprender. Se eu fosse homem, seria dono de festa como meu pai. Meu filho não deixa. Por isso não sou dona de festa. Murey'ra queria que Piré fosse dançarina Tauva mas ela não quis e teve filho. Eu queria mandar meu filho aprender com Murey'ra. Mas o pessoal fala que eu não posso fazer, então também não mando meu filho aprender. Pensam que eu falei que sei dançar na festa do Tauva, mas eu não falei isso. Eu vou mandar meu filho aprender". 
O tema da utilização do registro em vídeo para a transmissão dos saberes tradicionais se articula, nos depoimentos, aos dos processos de ensino e aprendizagem entre gerações. Este entendimento também se manifestou com a realização do ritual Arapoá para a iniciação de Takamuim, já anunciada segundo ele através de sonho que tivera no ano passado e uma vontade que foi desenvolvida ante as dificuldades que, também conforme sua avaliação, vêm encontrando nos últimos tempos de serem adequadamente assistidos pelo órgão do governo (Funai). No depoimento que precede a narrativa do sonho xamanístico, Takamuim afirma que os brancos não fornecem mais, como em outras épocas, medicamentos suficientes para atender os casos de doença, alegando que os recursos financeiros tornaram-se escassos. Isto efetivamente coincide com a degradação pela qual passa o sistema de assistência à saúde dos povos indígenas que foi transferido da responsabilidade da Funai para a do Ministério da Saúde, passando o órgão indigenista a ser subordinado administrativamente ao Ministério da Justiça. Não só Takamuim, mas também Manduka manifestou intenção de se tornar xamã respondendo à pergunta sobre o motivo de realizarem o ritual Arapoá: "Antigamente é que começou festa do veado e faz até agora. Antigamente tinha só um pajé que sabia festa do veado. Depois teve outro para ajudar e aí outro, outro e aí teve outros. Antigamente só tinha um. Depois teve outros donos da festa do veado. Vamos fazer para você pegar para depois ver na televisão. Vamos fazer a festa do veado para ver nosso desenho na televisão. Agora que começou, para fazer pajé novo tem de continuar e fazer direto. Vamos fazer festa para a gente ver dentro da televisão. O que está dentro da televisão poderá ser visto depois. Vão ver na televisão como os que vão morrer faziam. Vão ver o desenho deles".

O ritual se iniciou como havia sido anunciado e durante todo o período em que permanecemos na aldeia, as sessões se repetiam todas as noites, aguardando-se que Takamuim passasse pela experiência de ter introduzido em seu corpo o ka'á, uma substância que pode ser de origem vegetal em sua forma física, como um informante explicou (Müller, 1990: 180). Essa 
introdução se dá nos momentos de transe dos xamãs que participam do ritual e, em torno do iniciante, tentam através do contato corporal transmitir-lhe o ka'á. O iniciante também deve se encontrar em estado de transe, chamado yngaiva, cuja descrição do estado físico pelos Asuriní, em português, é "tremor". Um estado físico debilitado por doença é a condição propícia para o neófito receber a substância em seu corpo, para "pegá-la" (ka’á opyhyk). Após alguns dias depois de iniciado o ritual, Takamuim deu seu depoimento sobre a experiência a que se submetera nos seguintes termos: "Se continuar tremendo, caindo, levantando, hoje à noite quem sabe eu posso pegar. Eu ainda não estou muito tonto, mole, ninguém ajuda, só o Murey'ra. Sonhei que cheguei num lugar onde se põe $k a$ 'á no cigarro. Na boca da noite outro pajé vai fazer festa. Quando tremer demais, aí vem o ka'á que entra no corpo. Quando está doente é mais fácil de pegar, quando não está, sem doença, é mais difícil virar pajé. O pajé tem de continuar, tremer, tremer, tremer até cair, pegar, morrer. Vamos ver se hoje à noite eu pego, estou tremendo, mas ainda é pouco. Antigamente tinha muito pajé para ajudar virar pajé. Morreram quase todos os pajés. Com Morabô ${ }^{9}$ também foi assim, demorou. Tremeu, tremeu, tremeu, desmaiou, desmaiou, desmaiou, primeiro pegou espírito do veado, depois apykwara ${ }^{10}$, depois tivá ${ }^{11}$. Desmaiou, foi para o mato. Eu também vou desmaiar. Estou tremendo primeiro no pulso, depois no pé direito, esquerdo, vai subindo até as costas, vai subindo até a cabeça, aí não sobe mais, cabeça fica grande. Eu já consigo ficar tonto". O sonho de sua iniciação também começa por uma situação de doença, provocada pelo homem branco: "Branco antigamente encontrou Asuriní, fez café. O café fez mal, não tinha açúcar. Encheu o copo, branco queria me matar. Eu não posso tomar café ruim, tomei só uma vez. Tomei café e vomitei. Branco deu comida, deu comida, deu arroz, deu arroz, espírito de branco deu comida e eu vomitei".

No ritual que se desenrolava, entretanto, Takamuim não se encontrava doente e até o dia de nossa partida não havia ainda sido introduzido o $k a$ 'á em seu corpo. Tive notícia de que acabaram desistindo de tornar Takamuim um xamã. Lograram, entretanto, poder contar com a possibilidade de ver 
o "desenho" de "como se faz pajé" "dentro da televisão". O vídeo Morayngava deverá em breve ser exibido aos Asuriní. Para atingir este objetivo tiveram de reelaborar concepções e colocar em risco a própria tentativa de introduzir o $k a$ 'á no corpo de Takamuim ao permitirem que, para filmar o momento em que isto ocorre, uma iluminação perigosa ameaçasse seu êxito e invertesse drasticamente uma das condições mais essenciais ao transe dos xamãs, o lusco-fusco do ambiente. Nos 21 anos em que estive com os Asuriní em seus rituais xamanísticos, jamais vivi a situação de ter uma luz razoável ao menos para obter uma foto sofrível desse momento. Até o gravador de som que usei certa vez para registrar este momento foi responsabilizado pelo fracasso de não se conseguir introduzir o ka'á no corpo do xamã iniciando. Dessa vez, tínhamos direito a toda luz que dispúnhamos. Apenas nesse primeiro dia... Nos dias subseqüentes fomos instados a não direcionar a luz sobre os xamãs em transe, ou seja , na escuridão da noite, sem esta chance, não tivemos mais condição de captar imagens de uma das principais partes do ritual xamanístico e, certamente, a essencial para "se fazer um pajé". Tivemos sorte de que ficaram ótimas as imagens captadas na primeira e única vez.

Não só a excessiva luminosidade interfere nos processos de transformação que ocorrem no ritual xamanístico, os quais envolvem transmissão de substâncias entre corpos e entre seres de domínios cósmicos diferentes, situações liminares e perigosas que podem até levar à morte, como também a reprodução da imagem dos seres humanos pela fotografia é considerada uma ameaça a sua vida. A câmera fotográfica suga o ynga (princípio vital) da pessoa fotografada ao reproduzir sua imagem, ayngava. Nos momentos de reflexão suscitados pelas entrevistas realizadas, os depoimentos que transcrevemos a seguir exemplificam a construção de sentidos (concepções) que emerge de uma situação particular, a presença da televisão e da imagem em movimento nela reproduzida, colocando nova experiência de interlocução com os brancos e entre os próprios membros do grupo.

Manduka: "Nosso desenho está dentro da televisão. De quem é o desenho? É desenho de nossa festa. É bonito para ver depois na televisão. 
Foi a primeira vez que nós vimos o desenho de outro índio na televisão. Eu já tinha visto porque ando bastante por aí, mas todos os Asuriní estão vendo pela primeira vez. Nós gostamos de ver. Se não gostássemos não iríamos ver, mas como gostamos a gente vem ver. Nós gostamos de ver nosso desenho. Vamos fazer festa para a gente ver dentro da televisão. Ainda bem que estão fazendo na minha casa. Vão me pintar, pôr missanga para ficar bonito para a festa. Antigamente quando encontraram com branco ficoram com medo de gravador e fotografia. Os antigos tinham medo de gravador. Os mais velhos tinham medo. Eles tinham muito medo mesmo. Tinham medo de gravador. Eles pensavam que pegava ynga deles e por causa disso eles morriam. Ficava com medo do gravador. Depois viram que não morria, aí não ficaram mais com medo. Quando o padre Antônio $^{12}$ encontrou com eles ele tirou fotografia e aí homem morreu, não agüentou. Agora não ficou mais com medo, agora gosta. Isto que vocês estão filmando vai mostrar para as crianças, por isso a gente gosta. Quando eu morrer, vou ficar assim barrigudinho na televisão. O meu desenho vai ficar assim. Aí vão perguntar porque sou barrigudo e eu vou responder que minha mãe me fez assim. Antigamente nós tínhamos medo, agora nós não temos mais, agora podemos ver. Agora pode ver tauva, turé, ver homem no turé, ver mulher no tauva. Enquanto a Okina está viva é bom gravar. Depois liga o gravador quando ela morrer, outros podem aprender. Outros vão poder ver maritykaiva (especialista, "dona") do tauva. $\mathrm{O}$ pessoal vai dizer que era assim que antigo fazia. O que está dentro da televisão poderá ser visto depois".

Além dessas reflexões, os nomes dados pelos Asuriní à televisão, à imagem em movimento, à câmera de vídeo permitem algumas considerações sobre a experiência de seu contato com um instrumento tecnológico que logo incorporaram como meio de transmissão da cultura, aprendizagem e transmissão de conhecimento. Antes de tratar desses dados, é elucidativa, para se avaliar esta apropriação, a comparação feita por eles entre o filme e a narrativa do xamã sobre o mundo dos espíritos. Após assistirem a um filme de ficção, A guerra do fogo, sobre o embate entre duas tribos de 
homens primitivos, uma delas de homens-macacos e com minha explicação de que eram nossos (dos brancos) antepassados, o que os divertiu muito, um dos espectadores dessa sessão comentou que com este filme fazia-se o mesmo que os xamãs fazem quando contam suas viagens cósmicas: fazem existir como realidade acontecimentos e lugares só conhecidos por estes. O filme A guerra do fogo fazia existir o passado mítico do homem branco. Os sonhos do xamã e a imagem em movimento são narrativas que fazem existir realidades virtuais, as que se encontram no espaço e tempo mítico, mas também as que serão passado histórico no futuro das novas gerações (“o que está dentro da televisão poderá ser visto depois, vão ver na televisão como os que vão morrer faziam", "quando nós morrermos as crianças poderão ver como fazíamos festa").

O vídeo Morayngava se inicia com um depoimento de Manduka dizendo "o que está dentro, mexendo, é morayngava, esse aí (apontando para a câmera de vídeo) é moresakava".

Moro é prefixo que indica nome coletivo, $a v(a)$ é sufixo formador de circunstância. Traduzi anteriormente, em minhas pesquisas sobre os Asuriní, ayngava por imagem, réplica, representação (Müller, 1990: 245), diferenciando o termo "desenho", tradução de ikwasiat, nome dado ao grafismo geométrico da pintura corporal, da decoração da cerâmica e do trançado (:206). Assim temos, como tradução de morayngava, "a imagem das coisas" (imagem no sentido coletivo de imagem de tudo). Nos últimos anos, com maior tempo de contato com a língua portuguesa e com a alfabetização da escola, os Asuriní passaram a usar a palavra "desenho" para traduzir ayngava. Por isso, na tradução dos depoimentos, feita por Takirí, nos depoimentos em português e nas legendas do vídeo, morayngava é "o desenho das coisas", e orerayngava é "o nosso desenho".

Moresakava, nome dado à câmera de vídeo, é o mesmo dado à câmera fotográfica e a espelho, literalmente, o que vê as coisas (moro=prefixo de nome coletivo, oesak=ver, av(a)=sufixo formador de circunstância).

Manduka se referiu ainda à imagem em movimento na televisão como a "sombra" do corpo humano, denominada ynga pelos Asuriní e que traduzi por princípio vital, substância vital que anima o corpo. Além da 
sombra, é a voz, a pulsação do corpo e do coração (Müller, 1990: 170). A morte é a perda do ynga. Os Asuriní dizem que a febre, na doença, causa o suor, ynga que o corpo está perdendo. Desses aspectos semânticos do significado da palavra ynga, interessa em particular o de "sombra", princípio vital visualizado mas sem matéria. A escolha da palavra "sombra" por Manduka faz referência ao movimento, comparando em seu depoimento com um gesto, sua própria sombra que se mexia, à imagem em movimento na televisão. A palavra ynga, portanto, aquilo que anima, que movimenta, a substância vital dos seres animados foi traduzida no vídeo por "alma", que remete a estas idéias na língua portuguesa.

Nos depoimentos de Maracauá e Apebu temos que a câmera de vídeo põe a imagem (desenho) dentro da televisão, oreayngava onhynhyn (nosso desenho está entrando), e assim fazendo, "o yng a fica guardado dentro" (oreynga pupé). Daí o nome dado à televisão yngirú, o que guarda/contém ynga, traduzido na legenda do vídeo por "caixa de alma". A conceituação elaborada por Manduka, Maracauá e Apebu se assenta na relação entre as noções de imagem/representação (ayngava) e princípio vital (ynga) que desenvolvi na pesquisa sobre arte gráfica e ritual Asuriní ${ }^{13}$. A conclusão sobre esta relação é que, para os Asuriní, a “imagem”, ela própria, é constitutiva da pessoa (enquanto ser), distinguindo-se do princípio vital/substância, ynga, por sua reprodução plástica, mas igualmente princípio vital e não apenas reprodução, no sentido de representação de algo ausente.

\section{Conclusão}

Neste trabalho de Antropologia, tema de investigação e metodologia se confundem pois, ao se utilizar instrumento tecnológico para registro, análise e divulgação da pesquisa, a apropriação do instrumento pelos indivíduos pesquisados passou a ser constitutiva da realidade estudada. E, na produção do vídeo como texto antropológico, a performance ritual é parte do mesmo. Antropologia construída por pesquisador e pesquisado. O principal tema deste estudo, transmissão de conhecimento e reprodução da cultura, 
foi abordado através de uma experiência intercultural: em resposta ao contato com sua imagem na televisão, proposto pelo pesquisador, os Asuriní realizaram performance de representação, procurando dar sentido aos desafios do processo de conhecimento instaurado pelo meio de representação da antropóloga.

Um ritual xamanístico realizado para ser captado pela máquina do branco e devolvido para reprodução e continuidade da cultura indígena é uma "experiência formativa", ou seja, manifestação expressiva de estrutura processual através da qual "significados que informam o repertório humano vital do pensamento, do desejo, do sentimento são colocados em circulação" (Turner \& Bruner, 1986: 37).

Nessa experiência, conceitos como representação, imagem, substância vital foram ressignificados na performance corporal que expressa estes conteúdos, os mesmos que constituem as mensagens transmitidas e igualmente ressignificadas através do meio tecnológico de expressão da cultura do pesquisador.

Esta experiência intercultural proporcionou, portanto, reflexão antropológica sobre processos que envolvem transformação e continuidade cultural em sociedades indígenas, particularmente, processos de produção de sentido e de transmissão de noções de conhecimento que dão expressão à experiência vivida como reflexividade transformadora. Foram então investigados fenômenos que se conceituou como performances culturais, em particular os rituais, estruturas de experiência que integram aspectos cognitivos, afetivos e volitivos.

Quero finalizar este trabalho com uma reflexão de caráter mais geral. Pensar a dança no ritual e a imagem em movimento na televisão me permitiram atingir a essência do primeiro e do último insight dessa pesquisa sobre o corpo em movimento, iniciada há dez anos. Nesta ocasião, encontrei a expressão do primeiro na definição de dança para Suzane Langer: "ilusão de conquista da gravidade", a experiência de transcendência da condição humana. Para além do corpo, há uma alma no corpo em movimento. E os Asuriní me ensinaram, no final desse ciclo de minha atividade de pesquisa, que a imagem do corpo em movimento é a alma. 
Regina Polo Müller. Corpo e Imagem em Movimento: há uma alma neste corpo

\section{Notas}

* Este trabalho teve o apoio do Projeto Temático Antropologia, História e Educação: a questão indígena e a escola, financiado pela FAPESP e realizado pelo MARI - Grupo de Educação Indígena - USP

1 Deste estudo resultaram dois trabalhos apresentados em reuniões científicas e um capítulo de livro (Müller, 1994a , 1994b, 1998).

2 A população chegou a 52 indivíduos em 1982 e em 1997 contava perto de 90.

3 Do ritual indígena à performance artística, projeto de pesquisa desenvolvido no Departamento de Artes Corporais/Unicamp, em 1996, e Educação formal diferenciada e processos de transmissão de conhecimento e aprendizagem: arte gráfica e ritual dos Asuriní do Xingu, sub-projeto do projeto temático Antropologia, História e Educação: a questão indígena e a escola, Centro MARI/USP, Fapesp ,1994.

4 Vídeos do projeto Vídeo nas aldeias/Centro de Trabalho Indigenista, através do qual foi realizado o vídeo Morayngava.

5 Chamo os tivá, apykwara e karovara de espíritos xamãs-primordiais como referência à sua condição de habitantes de outra esfera cósmica e à função que desempenhavam no passado mítico, estando associados à cura das doenças. Semelhantes aos espíritos xamãs-primordiais, do ponto de vista de seu contato com os humanos, através dos rituais xamanísticos, habitando, igualmente, outras esferas cósmicas e constituindo espécies cujos indivíduos também possuem nomes próprios, são os porco-do-mato (tajaho) e veado (arapoá), associados às atividades de caça e agricultura. Chamo-os espíritos “animais" (Müller,1990: 190).

6 "Com a morte de xamãs importantes, Murey'ra (...) passou a concentrar a liderança religiosa e de outros assuntos de interesse coletivo da aldeia: a construção da tavyve, excursões para expulsar invasores, e a participação em reuniões fora da aldeia, com outros índios, promovidas pelo CIMI, para reivindicarem direitos à sociedade nacional. Perderam-se xamãs importantes mas se ganhou um novo, Voaiva, cuja primeira iniciação deu-se em 1981 e a 
Revista de Antropologia, São Paulo, USP, 2000, v. 43 nº 2.

segunda em 1991. Voaiva casou-se com Piré (com 13 anos na época), filha de Manduka, passando para o grupo de Murey'ra, depois de deixar o casamento com uma das mulheres do grupo doméstico que habitava a tavyve (casa comunal em que enterra os mortos e se celebra o ritual cosmogônico das flautas turé ), em1976. Além da concentração da liderança religiosa nas mãos de Murey'ra, com a morte de vários xamãs, as principais mudanças que ocorreram na organização social dos Asuriní foram o fortalecimento do seu grupo doméstico, a dispersão do grupo de irmãs da antiga tavyve e a formação de famílias em torno de casamentos de mulheres Asuriní com índios de outros grupos (Arara, Parakanã e Kararâ̂). Quanto ao grupo doméstico de Murey'ra, este se casou com uma das irmãs de um dos grupos domésticos mais estruturados desde o contato(o das irmãs Maracauá e Muterí). Com isso, trouxe o xamã Baiô, deste grupo, marido da outra irmã, Moterí, para o seu próprio. Trouxe também para si o xamã Voaiva através do casamento deste com a filha de Manduka, cujo casamento anterior com Mirabô o tornara membro do grupo doméstico de Murey'ra, desde a aldeia do Ipiaçava" (Müller, 1994a: 6).

7 "Antes mesmo do contato, o controle da natalidade entre os Asuriní pode ser constatado pela baixa porcentagem da população infantil em 1971 e pelos casos de mulheres sem filhos(...) De 26 mulheres adultas, apenas dez geraram filhos, e das sete com mais de 45 anos, apenas uma. A natalidade entre os Asuriní obedece a regras culturais como o casamento poliândrico geracional - isto é, o casamento de uma mulher com um marido mais novo e um mais velho - para a existência de prole. Uma das justificativas dada pelos Asuriní para o controle da natalidade é a de que a inexistência do marido jovem impede a geração de filhos nos termos ideais desta sociedade. Outra regra ideal para a procriação é a idade das mulheres, variando entre 20 e 25 anos para o nascimento do primeiro filho. Há uma tendência também de que os filhos de uma família nuclear não excedam o número de dois indivíduos." Pode-se, estimar que, há mais de meio século, isto é, por volta de 1930, a população Asuriní correspondia a cerca de cento e cinqüenta indivíduos. Dessa época ao ano do contato (quando se calcula contavam cem indivíduos), o decréscimo populacional se deve ao ataque de grupos inimigos e já se verificava baixa taxa de natalidade (Müller, 1990: 48).

8 Na legenda do vídeo traduzi tauva por festa do espírito da água pois é o nome do sobrenatural que se invoca no ritual que leva a mesma denominação: a mulher detentora do saber da agricultura que, no passado mítico, abandona 
Regina Polo Müller. Corpo e Imagem em Movimento: há uma Alma neste corpo

o mundo dos humanos para viver nas águas. Traduzi tivá por "festa do pajé" pois tivá é o nome do ritual e do espírito xamã-primordial; kavara é o nome do ser mitológico que sobrevive no episódio da separação definitiva entre vivos e mortos realizada através do canto sobre estes últimos e que compreende, na atualidade do mundo dos humanos, ritual do mesmo nome, parte do complexo ritual das flautas turé (Müller, 1990), o qual foi traduzido por "festa do morto".

9 Morabô é o xamã iniciado mais recentemente. Tive oportunidade de presenciar parte de seu processo de iniciação em 1995.

10 Nome de espírito xamã-primordial.

11 Idem.

12 Anton Lukesch, padre católico que fez o primeiro contato amistoso com os Asuriní a partir do qual foram aldeados às margens do igarapé Ipiaçava junto a um posto indígena da Funai.

13 “A tradução da palavra ayngava em Asuriní é réplica, medida, imagem. Por exemplo: a estilização de uma ave (uirá), um objeto ritual feito de taquarinhas encapadas de algodão chama-se uiraraingava (imitação, imagem de uirá); o desenho de um homem é avarayngava (avá=gente); um pedaço de pau que serve de medida para marcar a planta de uma casa no chão é ayngava. Ayngava é o que substitui. Por outro lado, com o sufixo $t$, que indica possuidor humano, tayngava significa imagem, réplica do ser humano. Eé o nome do boneco feito de taquarinhas encapadas de algodão, figura antropomórfica usada pelos xamãs e auxiliares em alguns rituais do maraká. O traço mínimo do padrão de desenho tayngava pode ser considerado o braço/perna desta figura, como indicaram as mulheres Asuriní ao identificá-lo. Como elemento simbólico representado pelo boneco, o tayngava representa o princípio constitutivo da categoria de humano (isto é, vivente, uno), compartilhado pelos espíritos, xamãs primordiais e animais da floresta. A substância ynga, princípio vital, é comum a estes seres, como já vimos, e apesar de se tratar apenas de uma semelhança morfofonêmica entre as duas palavras yng (a) e ayng (av)(a), pois designam coisas diferentes, o significado de uma constitui (é parte de) o significado da outra. É o que tentarei demonstrar. Ynga (raiz yng) é princípio vital e ayngava (raiz ayng) é imagem, representação, réplica. 
Revista de Antropologia, São Paulo, USP, 2000, v. 43 nº 2.

Na língua tupinambá, segundo os cronistas e missionários, ang é a alma e $a$ 'ang é imagem, palavras com significado diferente e sem relação, aparentemente, uma com a outra. Pela observação do uso de uma representação em particular, a de ser humano/vivente/uno, isto é, o tayngava, boneco antropomórfico no ritual xamanístico maraká, temos que, além de representação, ela própria se constitui no princípio que define humanos e outros seres viventes, isto é, que possuem a substância ynga. Os maraká, como vimos, tratam das relações entre seres de domínios cósmicos diferentes, através dos processos de transubstanciação e consubstanciação do ynga e da passagem deste de uns para os outros, através do xamã. $\mathrm{O}$ boneco antropomórfico do maraká, além de objeto simbólico, é um elemento que pode provocar, ele próprio, processos incontroláveis. Substância que passa de um ser a outro, diferentes entre si, de um plano cósmico a outro, diferentes entre si, o ynga, em sua representação plástica, é perigoso. Quando pedi a um assistente de xamã que me confeccionasse um tayngava, ele se recusou inicialmente alegando que poderia causar a morte dos xamãs (fora do contexto ritual e sem controle, portanto). Depois, disfarçadamente, enquanto falava comigo, e com o material que tinha às mãos ( a sua frente estavam talas de palha de babaçu que vinham sendo preparadas para a confecção de um cesto), fez uma pequena réplica, facilmente disfarçável em nossas mãos, depois de pronta. O perigo do tayngava está na representação/consubstanciação do elemento básico de manipulação do xamã, o ynga, perigoso por sua própria função de intermediação, mistura de planos, status e seres diferenciados. Etimologicamente distintas (e a língua tupinambá, segundo missionários e cronistas, apresenta esta diferença), as palavras ynga e ayng(av)(a) são conceitos que se interpenetram como partes de uma mesmo noção; o vivente, o uno, status atribuídos à existência de um princípio/ substância que também possui representação plástica e que é, ao mesmo tempo, local de consubstanciação do ynga, princípio vital. Pode-se levantar a hipótese de que a similaridade morfofonêmica contribui para um uso semântico similar, isto é, $y n g(a)$ e ayng(av)(a) significando o princípio ontológico que define o vivente, uno, princípio vital. A palavra tayngava que significa "imagem humana" não denomina simplesmente a figura humana, assim como a figura antropomórfica do objeto xamanístico e elemento básico da "grega", na arte gráfica Asuriní, não representam o corpo humano (Müller, 1990: 244-6). 
Regina Polo Müller. Corpo e Imagem em Movimento: há uma alma neste corpo

\section{Bibliografia}

MÜLLER, R.P.

1990 Os Asuriní do Xingu, história e arte, Campinas, Editora da Unicamp, Série Teses.

1994a Asuriní do Xingu: transformações e sobrevivência, Grupo de Trabalho "Florestas e Povos Amazônicos: desafios e transformações", 19a Reunião Brasileira de Antropologia, Niterói.

1994b Xamanismo Asuriní: discurso da resistência, Simpósio "Del ambiente amenazado al ambiente amenazante, la percepción indígena”, $48^{\circ}$ Congresso Internacional de Americanistas, Estocolmo, Uppsala.

1998 "O corpo em movimento e o espaço coreográfico: antropologia estética e análise do discurso no estudo de representações sensíveis", in NIEMEYER, A. M. \& GODOI, E. P. (org.), Além dos territórios: um diálogo entre a etnologia indígena, os estudos rurais e os estudos urbanos, São Paulo, Campinas, Mercado de Letras/Departamento de Antropologia, IFCH/UNICAMP.

\section{TURNER, V.}

1982 "From Ritual to theatre. The Human Serioness of Play", Performance Arts Journal Publications, New York, vol. 4.

1988 The Anthropology of Performance, New York, PAJ Publications.

TURNER, V. \& BRUNER, E. (ED.)

1986 The Anthropology of Experience, Chicago, University of Illioins Press.

1990 “Are there universals of performance?”, in SCHECHNER, R. \& APPEL, W. (org.), By Means of Performance, Cambridge University Press. 
Revista de Antropologia, São Paulo, USP, 2000, v. 43 nº 2.

\begin{abstract}
A shamanic ritual of initiation performed by the Asuriní of the Xingu river to be registered by video as well as the video itself are analysed, to address knowledge transmission in this society. This is done from the historically contextualized social experience and acomplished in the extent of what could be named cultural performance. In this experience, concepts such as representation, image, vital substance were re-signified by body performance that expresses these concepts, the same ones that are re-signified through the researcher's technological medium of expression. This intercultural experience provided anthropological reflexion about processes of transformation and cultural continuity in indigenous societies, particularly about the production of meaning and notions of knowledge that give expression to the atual experience as transformative reflexivity.
\end{abstract}

KEY- WORDS: Cultural performance, shamanic ritual, image, representation, Anthropology of Experience, Asuriní of the Xingu river.

Recebido em junho de 1999. 